\title{
Carbon Stock Changes in Soil and Aboveground Biomass from House Lot Development in King County, Washington, USA
}

\author{
Stephen Porder $^{1}$, Deborah Lipson ${ }^{2}$, Robert Harrison ${ }^{3}$ \\ ${ }^{1}$ Ecology and Evolutionary Biology, Brown University, Providence, USA \\ ${ }^{2}$ Center for Environmental Studies, Brown University, Providence, USA \\ ${ }^{3}$ College of Forest Resources, University of Washington, Seattle, USA \\ Email: stephen_porder@brown.edu
}

Received November 28 ${ }^{\text {th }}$, 2011; revised December $28^{\text {th }}$, 2011; accepted January $6^{\text {th }}, 2012$

\begin{abstract}
Fossil fuel burning and deforestation have driven dramatic increases in atmospheric $\mathrm{CO}_{2}$ since the industrial revolution. However, forests in the northern temperate region sequester a substantial $\left(\sim 0.6 \mathrm{Pg}^{\mathrm{yr}} \mathrm{yr}^{-1}\right)$ amount of carbon (C), largely through the regrowth of secondary forests that were originally cleared for timber over one hundred years ago. In the United States, however, some regions are approaching a maximum regrowth as forests are cleared again, this time for suburban and exurban development. Here we explore the effects of such development on C stocks in King County, WA, an area with high forest cover but rapid suburban expansion. We measured soil and biomass $\mathrm{C}$ on 18 paired-house/forest lots, and found house lots stored $\sim 80 \mathrm{Mg} \cdot \mathrm{C} \cdot \mathrm{ha}^{-1}$ less soil C, and between 130 and $280 \mathrm{Mg} \cdot \mathrm{C} \cdot \mathrm{ha}^{-1}$ less above-ground biomass $\mathrm{C}$ than adjacent forest lots. Combining soil $\mathrm{C}$ losses with estimates of $\mathrm{C}$ emissions from forest products yields average $\mathrm{C}$ emissions of $130-280 \mathrm{Mg} \cdot \mathrm{C} \cdot \mathrm{ha}{ }^{-1}$, with the majority of losses occurring at the time of lot conversion. As a comparison, suburban dwellers drive $~ 30 \%$ more than city residents, but this increase in annual emissions from increased driving is $1 \%-2.5 \%$ of the losses of $\mathrm{C}$ associated with converting forests to house lots. If forestland conversion in the Seattle area continues apace, in the coming decades $C$ emissions each year from that land-use conversion will equal $\sim 4 \%$ of King County's $2008 \mathrm{C}$ emissions.
\end{abstract}

Keywords: Land-Use Change; Carbon; Urban Soils; Emissions; Urban Growth; Development

\section{Introduction}

Land-use change and the burning of fossil fuels have dramatically increased atmospheric carbon dioxide $\left(\mathrm{CO}_{2}\right)$ concentrations since the industrial revolution, to a level not seen during the past 650 thousand years (IPCC 2007). Carbon (C) sequestration in regrowing forests, particularly in the northern temperate forest of North America and Europe, has partially offset these emissions (Pacala et al., 2001; Schimel et al., 2001; Houghton, 2007). However, as reforestation in some areas reaches a peak, and suburban and exurban development begins to reverse forest regrowth (Wienert 2006; Dwyer et al., 2000), rates of $C$ sequestration may slow. In the United States, most current deforestation for suburban development occurs in forests that were previously cleared, either for agriculture or silviculture. Since urban and exurban landscapes account for 1.5 million $\cdot \mathrm{km}^{2}$, or about $25 \%$ of the conterminous US, and have grown at an average rate of $24,600 \mathrm{~km}^{2} \cdot \mathrm{yr}^{-1}$ for the past fifty years (Brown et al., 2005), the fate of $C$ in secondary forested landscapes undergoing conversion to housing bears closer examination.

Despite its potential importance, the effects of suburban development on soil and biomass $\mathrm{C}$ has only recently been assessed in several regions of the US (Pouyat et al., 2002). In two northeastern temperate cities, Boston and Syracuse, urban soils contained $\sim 60 \%$ less $\mathrm{C}$ than was stored belowground pre-evelopment, while in Chicago and Oakland soil C was slightly higher (4\% - 6\%) in urban soils (Pouyat et al., 2006). In more arid regions, including Phoenix (Oleson et al., 2006) and the
Colorado Front Range (Kaye et al., 2005; Golubiewski, 2006; Qian \& Follett, 2002), C was higher in residential soils than native grass or desert soils. Similar results from Larimer County, CO suggest that surface soils in urban lawns can contain as much as $65 \%$ more C than shortgrass steppe soils (Kaye et al., 2005), which is not surprising given low organic $\mathrm{C}$ in semi-arid systems and the increased growth on lawns in response to water and fertilizer. In general, urban areas in arid regions have higher soil $\mathrm{C}$ than surrounding ecosystems and urban areas in wet, forested regions have lower soil C (Pataki et al., 2006). Whether changes in soil carbon content translates to emissions to the atmosphere is less well understood. For example, in King County, WA, large developments ( $>4$ houses) typically remove all topsoil and ship it to a topsoil dump, whereas single house developments typically remove soil from a $60 \mathrm{~cm}$ foundation footprint and spread it around the rest of the lot. The emission $\mathrm{C}$ from these soils to the atmosphere may be quite different.

Similarly, quantifying development-driven C fluxes to the atmosphere for above ground biomass (AGB) depends on more than documenting differences in $\mathrm{C}$ stocks pre and post development, since the fate of forest products must be considered when calculating atmospheric $\mathrm{C}$ emissions from that land use change. The fate of woody biomass can vary (lumber, paper, mulch, fuel, non-harvest residue), and with it the $\mathrm{C}$ released to the atmosphere. Estimates of $\mathrm{C}$ losses to the atmosphere from post-harvest biomass range between 30\% - 77\% over 90 years (Harmon et al., 1996; Heath et al., 1996; Perez-Garcia et al., 2006). Scaling up quantified plot-level $C$ affects is also difficult 
given the spatial patchiness and complexity of urban landscape mosaics (Kaye et al., 2006).

The goal of this study was to explore the effects of forest to house lot conversion on soil and biomass C stocks in King County, Washington, US, an area with high forest cover but rapid suburban expansion. Like many local governments in the US, King County is trying to assess the sources of its greenhouse gas emissions, and has set the aggressive emission reduction target of bringing annual emissions 80\% below 2007 levels by 2050 (http://your.kingcounty.gov/exec/news/2007/pdf/ClimatePlan.pdf). However, while the county recognizes that deforestation increases emissions and has taken some action to curb urban encroachment into forests, the county does not currently include potential soil and biomass $C$ losses associated with development in its estimates of emissions. Thus we explored these $\mathrm{C}$ losses from development represented a substantial fraction of regional emissions given potential projected growth scenarios.

\section{Methods}

\section{Site Description}

Our 18 study sites were all in or around the City of Issaquah, Washington, US which covers an area of about $22 \mathrm{~km}^{2}$ in eastcentral King County to the east of Seattle and Lake Washington, in the foothills of the Northern Cascades. The climate is temperate, with an annual precipitation of $150 \mathrm{~cm}$ (Brown, 2008). The region is in the western hemlock zone, and supports a humid coniferous forest (Franklin \& Dyrness, 1973). The area is largely forested, with a mixture of private forestland and state forest; most of the forest was logged in the late 1800s and early 1900s, and thus is $\sim 100$ year old secondary growth (Robbins, 1985).

The population of King County grew from 1.3 million to 1.7 million between 1980 and 2000 and is expected to grow to 2.2 million by 2030 (http://www.wsdot.wa.gov/planning/wtp/datalibrary/population/PopGrowthCounty.htm). An estimated 18,000 ha of King County forestland were converted to urban and suburban uses between 1979 and 1989 (MacLean \& Bolsinger, 1997) and 36,400 ha were converted between 1988 and 2004 (Erickson \& Rogers, 2008). Similarly, some projections suggest that $21 \%$ of population growth in King County between 2000 and 2040 (362,000 people) will occur in unincorporated areas, many of which are forested (Puget Sound Regional Council, 2008).

King County estimates that development of individual lots for single family residences constituted $\sim 50 \%$ of all residential building permits for unincorporated areas (where much of the construction on forestland occurs) between 1998-2008 (King County Department of Development and Environmental Services, pers. Comm.). Across development types, fossil-fuel intensive lawnmowers, pesticides and fertilizers are sometimes used for lawn maintenance, and while this certainly would affect a lifecycle $\mathrm{C}$ analysis of development, we limit our analysis here to soil and biomass $\mathrm{C}$ loss. We focused our study on single home developments, because it was not possible to assess the fate of excavated topsoil that was transported off site (as is often done in larger housing developments in the region).

The sites we sampled spanned urban $\left(>386\right.$ people $\left.\cdot \mathrm{km}^{-2}\right)$, suburban $\left(115\right.$ - 385 people $\left.\cdot \mathrm{km}^{-2}\right)$, and exurban (19 - 114 people $\cdot \mathrm{km}^{-2}$ ) areas, though the majority were in suburban settings (http://www.census.gov/population/censusdata/urdef.txt). We selected only sites whose lots had been cleared for the development of $<5$ homes (15 of 18 were cleared as single house lots), which makes it probable that soil was not removed from the pro- perty during construction. Most of the houses were in hilly areas, because we restricted our analysis to forest-to-home conversions, and much of the flat land in the region had been previously cleared for agriculture. The house lots ranged in elevation from $23 \mathrm{~m}$ - $330 \mathrm{~m}$ a.m.s.l. The underlying soils were Inceptisols and Entisols (Alderwood, Everett, Beausite, \& Neilton soil series; Soil Survey Staff, 2008), which are typical of the glacial tillrich soils of the region.

The house lots ranged from 1 - 88 years since development (mean 28 years). Lot size (including uncleared forest areas) ranged from $590 \mathrm{~m}^{2}-28,000 \mathrm{~m}^{2}$, while the total area cleared ranged from $400 \mathrm{~m}^{2}-5300 \mathrm{~m}^{2}$, and the house footprint from $130 \mathrm{~m}^{2}$ $340 \mathrm{~m}^{2}$. The majority of the cleared area at each site was lawn, but the cleared area also included gardens, planted trees and shrubs, and lone trees left standing during the clearing process. Gardens accounted for $\sim 6 \%$ of cleared area on the average house lot. We drew house lot soil C samples from the lawn, and at two sites we also drew samples from gardens for comparison. We assumed that the intact forest left in place on the property did not lose any $\mathrm{C}$ during development.

\section{Soil Carbon Determination}

At each house lot we took three soil samples from the lawn (at 1,5 , and $10 \mathrm{~m}$ perpendicular from the house) and one sample from an adjacent forest site within $200 \mathrm{~m}$ of the lawn. There was no difference in soil $\mathrm{C}$ between lawns and gardens (Appendix 1), so these were combined in further analyses. We used a hammer core to a depth of $25 \mathrm{~cm}$ to determine bulk density (Grossman \& Reinsch, 2002). Bulk density is notoriously difficult to measure in rocky soils (Vincent \& Chadwick, 1994), and it was not possible to get home owner permission for the preferred method of excavating large areas quantitatively. Our use of a hammer core certainly introduces error to our bulk density measurements, but that error is equally distributed between our two land use types. In the hole created by the hammer corer we used a twist auger to collect three samples to a total depth of $75 \mathrm{~cm}(25 \mathrm{~cm}-42$ $\mathrm{cm}, 42 \mathrm{~cm}-59 \mathrm{~cm}$, and $59 \mathrm{~cm}-75 \mathrm{~cm}$ ). Because of the high rock and gravel content of the soil we were unable to sample to $75 \mathrm{~cm}$ at every location, but we collected at least one core per house, and one per forest, to a depth of $42 \mathrm{~cm}$ and to a depth of $59 \mathrm{~cm}$ for all but four houses and four forests. Since there were no differences in either bulk density or soil $\mathrm{C}$ in house lot soils as a function of distance from the house (Appendix 1), we averaged our house lot samples and considered a paired house lot/forest for each site.

We assumed, based on ten interviews with contractors, that $60 \mathrm{~cm}$ of soil was excavated from the house foundation and spread around the site (and therefore included in the soil $\mathrm{C}$ values for the lawn). Since the mean house size was only $20 \%$ of the mean cleared lot size (Appendix 1), this assumption is unlikely to substantially influence our results. We conservatively assumed no soil C loss from beneath the driveway.

All samples were air-dried at room temperature for a minimum of 48 hours and sieved through a $2 \mathrm{~mm}$ screen. We determined bulk density of the $<2 \mathrm{~mm}$ fraction for the $0 \mathrm{~cm}-25 \mathrm{~cm}$ core, and assumed bulk density did not change below $25 \mathrm{~cm}$. This assumption underestimates soil losses from house lots, since surface soils were significantly less dense in forests than in house lots ( 0.77 vs $1.0 \mathrm{~g} \cdot \mathrm{cm}^{-3}$, respectively, $\mathrm{p}=.003$; Appendix 1), and this difference likely gets smaller with depth. A subsample of each sample was ground in an agate mortar and pestle, dried at $65^{\circ} \mathrm{C}$ for at least 48 hours, and analyzed for $\mathrm{C}$ concentration on 
a Carlo Erba NC2100 model C/N analyzer. A second subsample was dried at $105^{\circ} \mathrm{C}$ and all stocks are reported per $105^{\circ} \mathrm{C}$ oven-dried mass. Samples were run in duplicate, and $10 \%$ were run in triplicate. Ninety-five percent of the standards run as unknowns were within $5 \%$ of their accepted value. All reported values are means \pm 1 S.E. unless otherwise noted. Statistical comparisons between forest and house lots were done in Matlab (Version 7.4, Mathworks, Inc.) via a paired t-test or ANOVA after testing that the data did not violate the assumptions of normality.

\section{Carbon in Biomass}

We did not measure biomass in forest lots adjacent to house lots, but instead calculated changes in AGB by comparing AGB on each house site with the range of forest AGB values reported for the Pacific Northwest $\left(140-290 \mathrm{Mg} \cdot \mathrm{C} \cdot \mathrm{ha}^{-1}\right.$; Adams et al., 2005; Binkley et al., 1992; Hutyra et al., 2011), though more recent estimates are somewhat lower. We chose to use a biomass range, rather than to measure forest biomass directly for two reasons: 1) allometric equations developed for tree species in the region are problematic (Harrison et al., 2009); and 2) biomass lost at the time of clearing would not be the same as biomass in adjacent forests today, particularly for older home sites. Rather than include a non-random error in our assessment we chose to assess a reasonable range of biomasses that could give us an idea of the importance of soil relative to biomass $\mathrm{C}$ losses.

Estimates of how much AGB C ends up as atmospheric C post-harvest also vary considerably, and we chose a range that encompasses the majority of the literature for these estimates. Heath et al. (1996) argued that $30 \%$ of biomass $C$ from cleared forests in the United States is emitted as $\mathrm{CO}_{2}$ over 90 years by decomposition of wood products, and another 35\% is emitted from biomass burning for energy. Because the latter likely replaces fossil fuels that would have been used anyway we do not consider this an additional loss of $\mathrm{C}$ associated with development per se, and use 30\% over 90 years as a lower bound of AGB loss. For an upper bound, we use an estimate of $77 \%$ loss (Harmon et al., 1996). Thus we assume that 40 - $222 \mathrm{Mg} \cdot \mathrm{C} \cdot \mathrm{ha}^{-1}$, less the amount of biomass still on the cleared portion of the house lot, are lost to the atmosphere in the 90 years after house development. We use 90 years as a time frame because it is appropriate for this study (the oldest house is $\sim 90$ years) and because both Heath et al. (1996) and Harmon et al. (1996) give aggregate emissions estimates based on $\mathrm{C}$ fate in forest products over this time period, since the collection period of the harvest data from the Forest Service was 1900-1990.

Biomass on each house lot was calculated by measuring diameter at breast height (DBH) for all trees on the site and using a generic allometric equation to determine biomass (Jenkins et al., 2004):

$$
\text { Above Ground Biomass }=\operatorname{Exp}\left(\mathrm{B}_{0}+\mathrm{B}_{1} \ln d b h\right)
$$

where $B_{0}=-2.4800$ and $B_{1}=2.4835$; these parameters are mean values for mixed hardwoods (most house lots contained a broad mix of native softwoods and non-native planted hardwoods). While these parameters are meant specifically for trees growing in a canopied forest, using other common estimates for $\mathrm{B}_{0}$ and $\mathrm{B}_{1}$ in this type of system resulted in changes of $<5 \mathrm{Mg} \cdot \mathrm{C} \cdot \mathrm{ha}^{-1}$. While some studies have shown that using allometric equations appropriate for trees in a canopied forest can overestimate biomass of urban trees by $\sim 20 \%$ (Nowak, 2004), to our knowledge this issue has not been explored in the Pacific Northwest, and other authors have argued that standard allometry may either over or under- estimate actual urban biomass (McHale et al., 2009). Regardless, there was so little biomass (mean $8 \mathrm{Mg} \cdot \mathrm{C} \cdot \mathrm{ha}^{-1}$ ) in house lots relative to forests (or soils) that the choice of allometric equation has very little influence on our results. We assumed AGB was 50\% C (Schlesinger, 1997), and omitted both grass and shrubs under $1 \mathrm{~m}$ tall, since they account for $<2 \%$ of total biomass in urban and suburban settings (Golubiewski, 2006; Jo \& McPherson, 1995). Finally, we conservatively assumed no belowground biomass loss because there was insufficient data to make a more nuanced estimate.

\section{Results}

\section{Soil Carbon}

The mean surface $(0 \mathrm{~cm}-25 \mathrm{~cm})$ soil C concentration was significantly higher in forests $(6.4 \% \pm .78 \%)$ than on house lots $(3.8 \% \pm .29 \%$; $=.00005$; Figure 1). Similarly, the $25 \mathrm{~cm}-75$ $\mathrm{cm}$ soils were significantly more $\mathrm{C}$ rich in forests than lawns $(3.6 \% \pm .65 \%$ versus $1.9 \% \pm .20 \% ; \mathrm{p}=.006)$. The mean bulk densities for the forest and house lots also differed significantly at $.77 \pm .24$ and $1.0 \pm .05 \mathrm{~g} \cdot \mathrm{cm}^{-3}$, respectively $(\mathrm{p}=.003, \mathrm{n}=18)$. These data indicate that forest soils stored $\sim 80 \mathrm{Mg}$ more $\mathrm{C} \mathrm{ha}^{-1}$ than house lot soils $\left(240 \pm 25\right.$ vs $160 \pm 11 \mathrm{Mg} \cdot \mathrm{C} \cdot \mathrm{ha}^{-1}$, respectively, $\mathrm{p}=.002$ ). There was no significant difference in $\mathrm{C}$ concentration between the three depths for the $25 \mathrm{~cm}-75 \mathrm{~cm}$ samples $(\mathrm{p}=.71)$ nor in bulk density or the means of the $\mathrm{C}$ concentration among the three distances from the house $(p=.55$ and .18 respectively). Finally, there was no correlation between house age, or lot size, and soil $\mathrm{C}$ concentration $(\mathrm{p}=.4$ and .2 , respectively).

\section{Carbon in Biomass}

The aboveground $\mathrm{C}$ in biomass on the house lots ranged from 0 $\mathrm{Mg}-44 \mathrm{Mg}$, with a mean of $8.0 \pm 3.0 \mathrm{Mg} \cdot \mathrm{C} \cdot \mathrm{ha}^{-1}$ (Figure 2). Native trees, left behind on clearing, made up $\sim 40 \%$ of the this biomass. There was no correlation between age and biomass on house sites $\left(r^{2}=.05, p=.38\right)$. Forest AGB C estimates drawn from the literature suggest that there is $140-290 \mathrm{Mg} \cdot \mathrm{C} \cdot \mathrm{ha}^{-1}$ in AGB (Adams et al., 2005; Binkley et al., 1992; Hutyra et al., 2011). Assuming between $30 \%$ and $77 \% \mathrm{C}$ emitted from this AGB over 90 years (Heath et al., 1996; Harmon et al., 1996) after conversion from forest to house lot, between $40-220 \mathrm{Mg} \cdot \mathrm{C} \cdot \mathrm{ha}^{-1}$ are likely lost to the atmosphere over this time. If loss rates are invariant over 90 years, this suggests emissions of $.40-2.4 \mathrm{Mg} \cdot \mathrm{C} \cdot \mathrm{ha}^{-1} \cdot \mathrm{yr}^{-1}$.

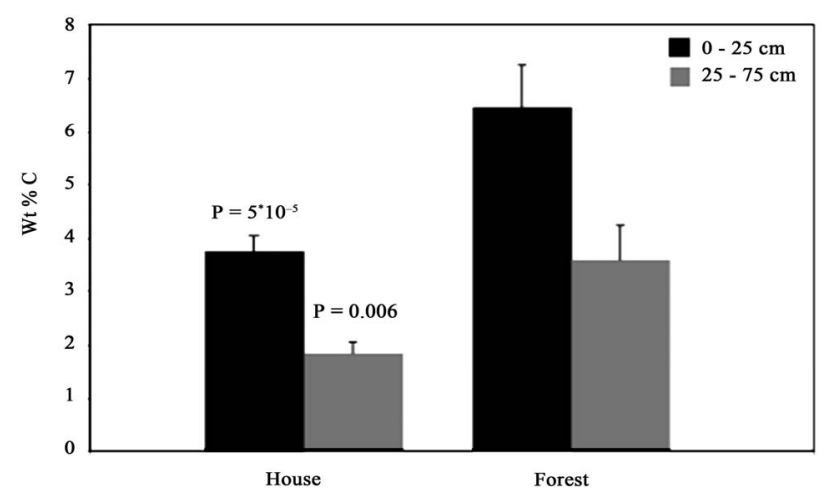

Figure 1.

Percent carbon in house lot soils and forest soils. The error bars represent $1 \mathrm{SE}$. p-values are from comparisons of forest and house soils at a given depth. 


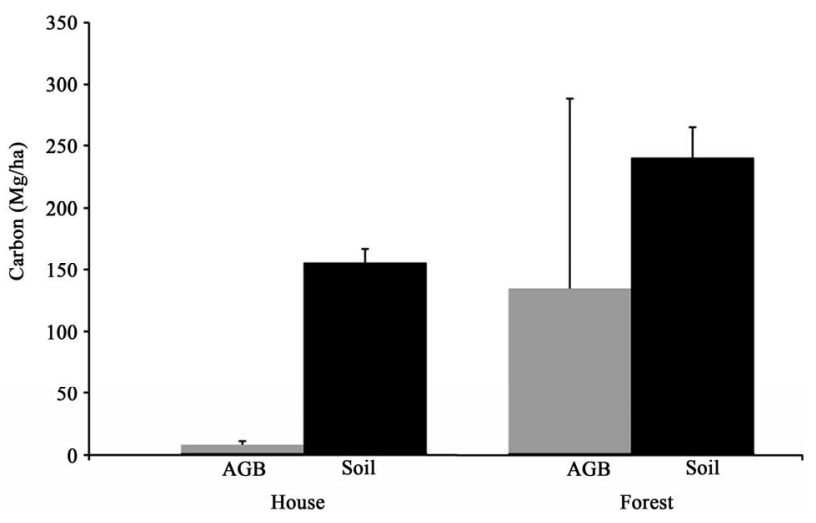

Figure 2.

Mean carbon stores in soil and aboveground biomass in house and forest lots. The error bars for the house lots and the forest soil represent 1 $\mathrm{SE}$. The error bar on forest AGB represent the range found in the literature for this region.

\section{Discussion}

\section{Soil Carbon and Biomass Loss}

Given the trajectory of suburban encroachment onto forests or reforested land, our results are important for those calculating greenhouse gas budgets in the Pacific Northwest. Our data suggest that a pulse of $\mathrm{C}$ is released from the soils of a house lot during development that does not re-accumulate over time. Furthermore, the soil C loss associated with lot development is

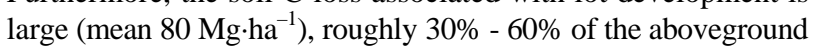
$\mathrm{C}$ loss. This finding is consistent with those of Pouyat et al. (2006) in cities with climates similar to that of this study, but contrasts with those of Golubiewski (2006), Kaye (2005) and Qian and Follett (2002), which found relatively higher C in urban soils in drier and/or warmer climates. Similarly, the lack of correlation between age of development and soil $\mathrm{C}$ contrasts with the results of those studies. We hypothesize that in wetter environments, such as the one in our study, development stimulates a pulse of decomposition that tapers off as the new land use is in place. In contrast, poor arid soils accumulate $C$ over time as water and nutrients are continually provided. These results support the review by Pataki et al. (2006) and Pouyat et al. (2009), both of which suggest that affect of development on soil $\mathrm{C}$ varies by ecosystem. Given the low biomass on house lots, the vast majority (>90\%) of $\mathrm{C}$ in house lots is stored in soils (Figure 2). Similar C distributions have been observed in other urban areas (Jo \& McPherson, 1995).

\section{Assumptions}

While understanding the $\mathrm{C}$ footprint of development is critical for planning how best to reduce emissions, there is considerable uncertainty in determining losses that bear closer examination here. Perhaps most importantly, we assume that soil C losses from the site result in $\mathrm{C}$ emissions to the atmosphere in the form of $\mathrm{CO}_{2}$ or that $\mathrm{C}$ originally in forest soils was decomposed and respired upon conversion to house lots. However, some fraction of house lot soil $\mathrm{C}$ that we measure as missing may actually have been transported off of the site via erosion of topsoil. The fate of such $\mathrm{C}$ is unclear, and likely depends on processing in rivers and estuaries (Berhe et al., 2007). This may lead us to overestimate emissions from soil C.
We also assume that bulk density was the same from $25 \mathrm{~cm}$ to $75 \mathrm{~cm}$ as it was from $0 \mathrm{~cm}-25 \mathrm{~cm}$ at each site, which propagates the higher bulk density in house lots to depth. If compaction did not affect the lower house lot horizons, and bulk density in the lower soil is similar between pairs of sites, we will overestimate the amount of $\mathrm{C}$ in house lots by $\sim 10 \%$.

In addition, the fate of AGB removed from the house lot greatly influences the magnitude of $\mathrm{C}$ lost. There is a dearth of data on the fate of $\mathrm{C}$ in harvested wood products, particularly on how long wood products used in construction take to decompose, and how that varies with wood type, specific use, and region. In addition, the time scale of these losses is poorly constrained. We took 90 years of losses as our benchmark, based on the available literature and the age of the homes in our study area. However, if these losses occur more rapidly, or if losses decrease exponentially with time, we may be considerably underestimating losses from house lot clearing.

\section{Lost Carbon Sequestration Potential}

Many of the forestlands into which Seattle is expanding were last logged in the late 1800s and early 1900s, meaning that most of these stands are currently around 100 years old (Robbins, 1985). Stands of Northwest evergreens, such as Douglas-fir and Western Hemlock, take up to 250 years to mature after being logged, and some conifers can live up to 700 years (Spies \& Franklin, 1996). Smithwick et al. (2002) found that on average an additional $338 \mathrm{Mg} \cdot \mathrm{C} \cdot \mathrm{ha}^{-1}$ would be stored in the biomass and soils of coastal Washington and Oregon forests if second growth stands were allowed to return to their maximum $\mathrm{C}$ holding capacity, and that the upper bound $\mathrm{C}$ potential for just the biomass of these old growth forest is $380 \mathrm{Mg} \cdot \mathrm{C} \cdot \mathrm{ha}^{-1}$.

For $\mathrm{C}$ losses, and loss rates, we have used a range of between $140 \mathrm{Mg} \cdot \mathrm{C} \cdot \mathrm{ha}^{-1}$ and $290 \mathrm{Mg} \cdot \mathrm{C} \cdot \mathrm{ha}^{-1}$ to estimate preclearing biomass (Adams et al., 2005; Binkley et al., 1992; Hutrya et al., 2011). However, the development of housing on regrowing forestland also represents a lost $\mathrm{C}$ uptake in the future. Assuming that the forests reach their full $\mathrm{C}$ holding potential after an additional 150 years (given an average stand age of $\sim 100$ years; Smithwick et al., 2002; Franklin et al., 1986), the lost sequestration potential (LSP) is the difference between the biomass at the time of removal and the assumed biomass of a fully grown forest. Lost sequestration potential at our sites ranges from 92 $245 \mathrm{Mg} \cdot \mathrm{C} \cdot \mathrm{ha}^{-1}$ developed, or .6 - 1.6 Mg.C $\cdot \mathrm{ha}^{-1} \cdot \mathrm{yr}^{-1}$ for the next 150 years. From the perspective of King County's emissions, this LSP represents a C sink that is lost by development that otherwise would have helped King County to reach its net $\mathrm{C}$ emissions reduction goals. Instead of this forested land acting as a $\mathrm{C}$ sink as the forest matures, when it is developed it acts as a $\mathrm{C}$ source as the biomass and soil $\mathrm{C}$ is emitted.

\section{Carbon Emissions in Context}

Although there are considerable uncertainties in the estimate, the C loss due to development is substantial, even when LSP or fossil fuel intensive inputs such as fertilizer and pesticides are left out of the equation. Assuming lower bound forest $\mathrm{C}$ and loss rates, $120 \pm 31 \mathrm{Mg} \cdot \mathrm{C} \cdot \mathrm{ha}^{-1}$ is liberated from soils and AGB within 90 years of conversion, while upper bound estimates suggest a $300 \pm 31 \mathrm{Mg} \cdot \mathrm{C} \cdot \mathrm{ha}^{-1}$ loss (Figure 2). This loss is comparable to other major $C$ costs of suburban development (Figure 3). For example, for every house that is built on a forest lot rather than 


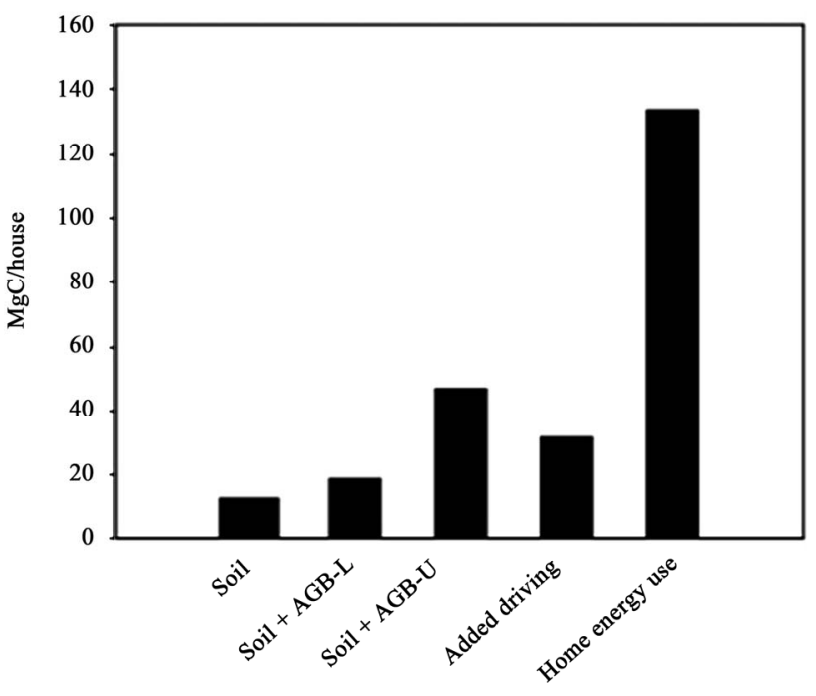

Figure 3.

Estimates for emissions from house lots over a time period of 90 years assuming a mean houselot size of .16 ha. Soil, above ground biomass low and high calculations as described in the text. Additional emissions from driving calculated assuming suburban households drive $31 \%$ more than urban households.

dense urban infill, there is on average a 31\% increase in the number of miles that that particular household drives (Kahn, 2000). If the average person in the Puget Sound region drives $~ 13,500$ $\mathrm{km} \cdot \mathrm{yr}^{-1}$ (Overby, 2008), a household with two drivers travels an additional $8000 \mathrm{~km} \mathrm{yr}^{-1}$ by building in suburbia compared to a similar household living in a denser urban area. Assuming an average car gets the 2004 CAFÉ standard of $11.7 \mathrm{~km} \cdot \mathrm{l}^{-1}(27.5$ miles per gallon) (EPA, 2003) and that emissions are 633 g.C $\cdot \mathrm{l}^{-1}$ (EPA, 2003), given a 99\% combustion efficiency, then the transportation-based $\mathrm{C}$ impact of building a single family home in the forest instead of as urban infill is .43 $\mathrm{Mg} \cdot \mathrm{C} \cdot \mathrm{yr}^{-1}$ (Figure $3)$. Thus it would take 30 years for the emissions from increased driving to equal just the soil $\mathrm{C}$ emissions from clearing 0.16 ha of forest, the mean area cleared at our sites (Figure 3, Appendix 1). It would take 43 - 107 years for increased tailpipe emissions to equal emissions from soil and biomass combined over 90 years, and even longer for driving emissions to equal soil and biomass emissions if LSP was included.

\section{Implications for King County and Future Directions}

Although the recent economic downturn and a new national awareness of environmental issues could slow Seattle's growth into forestland, it is likely that suburban encroachment into forest will still occur in the coming decades. Assuming that growth will roughly continue at the 1988-2004 pace, 36,000 ha will be converted from forestland to suburbs in the next 15 years in King County (Erickson \& Rogers, 2008). This means that emissions from soil and biomass C will likely be between 210,000 - 240,000 $\mathrm{Mg} \cdot \mathrm{C} \cdot \mathrm{yr}^{-1}$, or $\sim 4 \%$ King County's annual emissions, based on the county's 2008 emissions.

Such extrapolation is subject to considerable uncertainty. Not all of the land which is converted from forest to suburbs will be deforested and built as single house lots; according to estimates from the King County Department of Development and Environmental Services, single house lots likely represent just over half of total homes developed in the past decade around Issa- quah and similar suburbs. In large subdivisions or shopping centers the treatment of biomass and especially of soils is different, and therefore the $\mathrm{C}$ emissions may vary. Different soil types may respond to development differently, and because the sites in this study were located primarily in highland areas, riparian and other particularly soil C-rich areas were excluded. Despite this variation in both initial conditions and owner decision-making, these data demonstrate that emissions from house lot development can be a measureable fraction of total emissions in some regions. Given the rapid rate of suburban expansion in this country, we suggest the fate of biomass and soil $\mathrm{C}$ from different settings be a priority of future research across ecosystems.

\section{Acknowledgements}

We are grateful to Steven Hamburg and one anonymous reviewer for their helpful comments on a previous version of this manuscript. This work was supported by a Royce Foundation grant to D.L.

\section{REFERENCES}

Adams, A., Harrison, R., Sletten, R., Strahm, B., Tumblom, E., \& Jensen, C. (2005). Nitrogen-fertilization impacts on carbon sequestration and flux in managed coastal Douglas-Fir stands of the Pacific Northwest. Forest Ecology and Management, 220, 313-325. doi:10.1016/j.foreco.2005.08.018

Berhe, A., Harte, J., Harden, J., \& Torn, M. (2007). The significance of the erosion-induced terrestrial carbon sink. Bioscience, 57, 337-346. doi:10.1641/B570408

Binkley, D., Sollins, P., Bell, R., Sachs, D., \& Myrold, D. (1992). Biogeochemistry of adjacent Conifer and Alder-Conifer stands. Ecology, 73, 2022-2033. doi:10.2307/1941452

Brown, D. G., Johnson, K. M., Loveland, T. R., \& Theobald, D. M. (2005). Rural land-use trends in the conterminous United States, 1950-2000. Ecological Applications, 15, 1851-1863. doi: $10.1890 / 03-5220$

Brown, T. (2008). Period of record monthly climate summary. In: NOAA Washington Climate Summary. URL (last checked 20 December 2008). http://www.wrcc.dri.edu/cgi-bin/cliMAIN.pl?wa7468

Dwyer, J. F., Nowak, D. J., Noble, M. H., \& Sisinna, S. (2000). Connecting people with ecosystems in the 21st Century: An assessment of our nation's urban forests. United States Department of Agriculture Forest Service, PNW-GTR-4990.

Erickson, A., \& Rogers, L. (2008) Western Washington land use change. Rural Technology Initiative. http://www.ruraltech.org/projects/wwaluc/

EPA (2003). US inventory of greenhouse gas emissions and sinks 1990-2001. Washington DC: Office of Atmospheric Programs, US Environmental Protection Agency, EPA 430-R-03-004.

Franklin, J. F., \& Dyrness, C. T. (1973). Natural vegetation of Oregon and Washington. United States Department of Agriculture General Technical Report PNW-8. Portland, OR.

Franklin, J., Hall, F., Laudenslayer, W., Maser, C., Nunan, J., Poppino, J., Ralph, C. J., \& Spies, T. (1986). Old growth definition task group report: Interim definitions for old-growth Douglas-Fir and MixedConifer forests in the Pacific Northwest and California. USDA Forest Service, Pacific Northwest Research Station Research Note PNW-447.

Golubiewski, N. (2006). Urbanization increases grassland carbon pools: Effects of landscaping in Colorado’s front range. Ecological Applications, 16, 555-571. doi:10.1890/1051-0761(2006)016[0555:UIGCPE]2.0.CO;2

Grossman, R., \& Reinsch, T. (2002) Bulk density and linear extension In J. H. Dane, \& G. C. Topp (Eds.), Methods of soil analysis part IV: Physical methods (p. 1692). Madison, WI: Soil Science Society of America. 
Harmon, M., Harmon, J., Ferrell, W., \& Brooks, D. (1996). Modeling carbon stores in Oregon and Washington forest products: 1900-1992. Climatic Change, 33.

Harrison, R., et al. (2009). Biomass and stand characteristics of highly productive mixed Douglas Fir and Western Hemlock Plantation in Coastal Washington. Western Journal of Applied Forestry, 24, 180-286. doi:10.1146/annurev.earth.35.031306.140057

Heath, L., Birdsey, R., Clark, R., \& Plantinga, J. (1996) Carbon pools and flux in US forest products. Forest ecosystems, forest management and global carbon cycle (pp. 271-278). New York: SpringerVerlag.

Houghton, R. (2007). Balancing the global carbon budget. Annual Review of Earth and Planetary Sciences, 35, 313-347.

Hutyra, L. R., Yoon, B., \& Albert, M. (2011). Terrestrial carbon stocks across a gradient of urbanization: A study of the Seattle, WA region. Global Change Biology, 17, 783-797. doi:10.1111/j.1365-2486.2010.02238.x

IPCC (2007). Climate Change 2007: The physical science basis. Contribution of Working Group I to the Fourth Assessment Report of the Intergovernmental Panel on Climate Change. Cambridge: Cambridge University Press.

Jenkins, J., Chojnacky, D., Heath, L., \& Birdsey, R. (2004). Comprehensive database of diameter-based biomass regressions for North American tree species. United States Department of Agriculture General Technical Report NE-319.

Jo, H., \& McPherson, E. (1995). Carbon storage and flux in urban residential green space. Journal of Environmental Management, 45, 109-133. doi:10.1006/jema.1995.0062

Kahn, M. (2000). The environmental impact of suburbanization. Journal of Policy Analysis and Management, 17, 569-586. doi:10.1002/1520-6688(200023)19:4<569::AID-PAM3>3.0.CO;2-P

Kaye, J. P., McCulley, R. L., \& Burke, I. C. (2005). Carbon fluxes, nitrogen cycling, and soil microbial communities in adjacent urban, native and agricultural ecosystems. Global Change Biology, 11, 575-587. doi:10.1111/j.1365-2486.2005.00921.x

Kaye, J. P., Groffman, P., Grimm, N. B., Baker, L., \& Pouyat, R. (2006). A distinct urban biogeochemistry? Trends in Ecology and Evolution, 21, 192-199. doi:10.1016/j.tree.2005.12.006

MacLean, C., \& Bolsinger, C. L. (1997). Urban expansion in the forests of the Puget Sound Region. Resource Bulletin PNW-RB-225. Portland: USDA Forest Service.

McHale, M., Burke, I., Lefsky, M., Peper, P., \& McPherson, E. (2009). Urban forest biomass estimates: Is it important to use allometric relationships developed specifically for urban trees? Urban Ecosystems, 12, 95-113. doi:10.1007/s11252-009-0081-3

Nowak, D. J. (1994). Atmospheric carbon dioxide reduction by Chicago's urban forest. In: E. G. McPherson, D. J. Nowak, \& R. A. Rowntree (Eds.), Chicago's urban forest ecosystem: Results of the Chicago Urban Forest Climate Project. General Technical Report NE-186. US Department of Agriculture, Forest Service: 83-94.

Oleson, J., Hope, D., Gries, C., \& Kaye, J. P. (2006). A Baysian approach to estimating regression coefficients for soil properties in land-use patches with varying degrees of spatial variation. Environmetrics, 17, 517-525. doi:10.1002/env.789

Overby, K. (2008). Puget sound trends: Trends in vehicle miles traveled. URL (last checked 31 January 2009).

www.psrc.org/publications/pubs/trends/t2sep08.pdf.

Perez-Garcia, J., Lippke, B., Comnick, J., \& Manriquez, C. (2006). An assesment of carbon pools, storage and wood products market sub- stitution using life-cycle analysis results. Wood Fiber Science, 37, 140-148.

Pacala, S., et al. (2001). Consistent land- and atmosphere-based US carbon sink estimates. Science, 292, 2316-2320.

doi:10.1126/science.1057320

Pataki, D., Alig, R., Fung, A., Goliubski, E., Kennedy, C., McPherson, E., Nowak, K., Pouyat, R., \& Pomero Lankao, P. (2006). Urban ecosystems and the North American carbon cycle. Global Change Biology, 12, 2092-2102. doi:10.1111/j.1365-2486.2006.01242.x

Pouyat, R., Groffman, P., Yesilonis, I., \& Hernandez, L. (2002). Soil carbon pools and fluxes in urban ecosystems. Environmental Pollution, 116, 107-118. doi:10.1016/S0269-7491(01)00263-9

Pouyat, R., Yesilonis, I., \& Nowak, D. (2006). Carbon storage by urban soils in the United States. Journal of Environmental Quality, 35, 1566-1575. doi:10.2134/jeq2005.0215

Pouyat, R., Yesilonis, I., \& Golubiewski, N. (2009). A comparison of soil organic carbon stocks between residential turf grass and native soil. Urban Ecosystems, 12, 45-62. doi:10.1007/s11252-008-0059-6

Puget Sound Regional Council (2008). Vision 2040. In: Puget Sound Regional Council Documents. URL (last checked 18 September 2008).

http://psrc.org/projects/vision/pubs/vision2040/index.htm

Qian, Y., \& Follet, R. F. (2002). Assessing soil carbon sequestration in turfgrass systems using long-term soil testing data. Agronomy, 94, 930-935. doi:10.2134/agronj2002.0930

Robbins, W. (1985). The social context of forestry: The Pacific Northwest in the 20th Century. The Western History Quarterly, 16, 413-427. doi:10.2307/968606

Schimel, D. S., House, J. I., Hibbard, K. A., Bousquet, P., Ciais, P., Peylin, P., Braswell, B. H., Apps, M. J., Baker, D., Bondeau, A., Canadell, J., Churkina, G., Cramer, W., Denning, A. S., Field, C. B., Friedlingstein, P., Goodale, C., Heimann, M., Houghton, R. A., Melillo, J. M., Moore III, B., Murdiyarso, D., Noble, I., Pacala, S. W., Prentice, I. C., Raupach, M. R., Rayner, P. J., Scholes, R. J., Steffen, W. K., \& Wirth, C. (2001). Recent patterns and mechanisms of carbon exchange by terrestrial ecosystems. Nature, 414, 169-172. doi:10.1038/35102500

Schlesinger, W. (1997). Biogeochemistry: An analysis of global change (2nd ed.). San Diego, CA: Academic Press.

Smithwick, E., Harmon, M., Remillard, S., Acker, S., \& Franklin, J. (2002) Potential upper bounds of carbon stores in forests of the Pacific Northwest. Journal of Applied Ecology, 12, 1303-1317. doi:10.1890/1051-0761(2002)012[1303:PUBOCS]2.0.CO;2

Soil Survey Staff (2008). Soil survey of King County, Washington. In: Natural Resources Conservation Service, United States Department of Agriculture Soil Survey. URL (last checked 10 December 2008). http://soildatamart.nrcs.usda.gov/Survey.aspx?State=WA

Spies, T. A., \& Franklin, J. F. (1996). The diversity and maintenance of old-growth forests. In R. C. Szaro, \& D. W. Johnson (Eds.), Biodiversity in managed landscapes: Theory and practice (pp. 296-314). Oxford, New York.

Vincent, K., \& Chadwick, O. (1994). Synthesizing bulk density for soils with abundant rock fragments. Soil Science Society of America Journal, 58, 455-464. doi:10.2136/sssaj1994.03615995005800020030x

Wienert, A. (2006). From forestland to house lot: Carbon stock changes and greenhouse gas emissions from exurban land development in central New Hampshire. Masters Thesis, Providence: Brown University. 
Appendix 1. Soil Carbon, Bulk Density, Above Ground Biomass (AGB) and Selected Site Attribute Measurements.

\begin{tabular}{|c|c|c|c|c|c|c|c|c|c|}
\hline \multicolumn{10}{|c|}{ HOUSE } \\
\hline Site & $\begin{array}{l}\text { Distance from } \\
\text { house m }\end{array}$ & $\begin{array}{c}\mathrm{BD} \\
\mathrm{g} \cdot \mathrm{cm}^{-3}\end{array}$ & $\begin{array}{c}\text { wt } \% \cdot C \\
0-25 \mathrm{~cm}\end{array}$ & $\begin{array}{c}\text { wt } \% \cdot C \\
25-75 \mathrm{~cm}\end{array}$ & 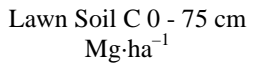 & Cleared Area ha* & House Area ha & $\begin{array}{l}\text { Total Soil C } \\
\text { Mg } \cdot \mathrm{ha}^{-1}\end{array}$ & $\begin{array}{l}\text { AGB-C } \\
\text { Mg ha }^{-1}\end{array}$ \\
\hline 1 & 5 & .88 & 3.3 & 1.7 & 150 & & & & \\
\hline 1 & 10 & .70 & 2.7 & 1.0 & 83 & & & & \\
\hline Site 1 mean & & .87 & 2.5 & 1.3 & 110 & .053 & .028 & 83 & 6 \\
\hline 2 & 1 & 1.4 & 1.9 & .79 & 120 & & & & \\
\hline 2 & 5 & 1.1 & .87 & .74 & 63 & & & & \\
\hline 2 & 10 & 1.1 & 4.2 & 1.4 & 180 & & & & \\
\hline Site 2 mean & & 1.7 & 2.3 & 1.0 & 190 & .082 & .013 & 170 & 20 \\
\hline 3 & 1 & 1.0 & 2.1 & 2.6 & 190 & & & & \\
\hline 3 & 5 & 1.2 & 2.9 & & & & & & \\
\hline Site 3 mean & & 1.5 & 2.2 & 2.0 & 230 & .042 & .025 & 150 & .5 \\
\hline 4 & 1 & .90 & 3.0 & 2.8 & 190 & & & & \\
\hline 4 & 5 & .93 & 3.3 & & & & & & \\
\hline 4 & 10 & 1.0 & 3.0 & 2.6 & 210 & & & & \\
\hline Site 4 mean & & 1.0 & 3.1 & 2.7 & 200 & .20 & .070 & 160 & .09 \\
\hline 5 & 1 & 1.0 & 2.7 & .84 & 110 & & & & \\
\hline 5 & 5 & 1.0 & 2.9 & 1.0 & 120 & & & & \\
\hline Site 5 mean & & 1.0 & 2.8 & 1.5 & 140 & .061 & .018 & 120 & 10 \\
\hline 6 & 1 & 1.3 & 2.9 & & & & & & \\
\hline 6 & 5 & 1.0 & 2.8 & .34 & 86 & & & & \\
\hline 6 & 10 & .83 & 2.8 & .37 & 73 & & & & \\
\hline Site 6 mean & & 1.0 & 2.8 & .36 & 91 & .021 & .022 & 59 & 30 \\
\hline 7 & 1 & 1.0 & 6.1 & 1.4 & 230 & & & & \\
\hline 7 & 10 & 1.0 & 7.2 & 2.2 & 300 & & & & \\
\hline Site 7 mean & & 1.0 & 6.3 & 1.7 & 250 & .018 & .018 & 170 & .3 \\
\hline 8 & 1 & .77 & 3.5 & .63 & 92 & & & & \\
\hline 8 & 5 & 1.4 & 4.6 & & & & & & \\
\hline 8 & 10 & .84 & 5.4 & 1.3 & 170 & & & & \\
\hline Site 8 mean & & 1.0 & 4.5 & 1.0 & 160 & .035 & .022 & 121 & 40 \\
\hline 9 & 1 & 1.3 & 3.9 & & & & & & \\
\hline 9 & 5 & 1.3 & & & & & & & \\
\hline 9 & 10 & 1.0 & 3.4 & 1.4 & 160 & & & & \\
\hline Site 9 mean & & 1.2 & 3.7 & 1.4 & 190 & .20 & .053 & 170 & $8^{* *}$ \\
\hline 10 & 1 & 1.0 & 5.0 & 3.1 & 290 & & & & \\
\hline 10 & 5 & 1.3 & 5.4 & & & & & & \\
\hline 10 & 10 & .89 & 4.5 & & & & & & \\
\hline Site 10 mean & & 1.1 & 5.0 & 3.1 & 300 & .070 & .018 & 240 & $8 * *$ \\
\hline 11 & 1 & .92 & 3.8 & & & & & & \\
\hline 11 & 5 & 1.0 & 3.2 & 1.6 & 150 & & & & \\
\hline 11 & 10 & .95 & 5.6 & 6.4 & 440 & & & & \\
\hline Site 11 mean & & .95 & 4.2 & 4.0 & 290 & .073 & .021 & 240 & 5 \\
\hline 12 & 1 & .67 & 6.8 & 3.5 & 230 & & & & \\
\hline 12 & 5 & .58 & 7.6 & 2.1 & 170 & & & & \\
\hline 12 & 10 & .67 & 4.8 & 2.3 & 160 & & & & \\
\hline Site 12 mean & & .64 & 6.4 & 2.6 & 190 & .021 & .015 & 140 & .1 \\
\hline 13 & 1 & .92 & 2.8 & 1.8 & 140 & & & & \\
\hline 13 & 5 & .80 & 4.5 & & & & & & \\
\hline
\end{tabular}


Continued

\begin{tabular}{|c|c|c|c|c|c|c|c|c|c|}
\hline 13 & 10 & 1.0 & 4.4 & & & & & & \\
\hline Site 13 mean & & .90 & 3.9 & 1.8 & 170 & .20 & .019 & 150 & .1 \\
\hline 14 & 1 & 1.1 & 3.8 & 2.4 & 240 & & & & \\
\hline 14 & 5 & 1.0 & 3.2 & & & & & & \\
\hline 14 & 10 & 1.3 & 4.2 & & & & & & \\
\hline Site 14 mean & & 1.1 & 3.7 & 2.4 & 250 & .10 & .016 & 220 & 1 \\
\hline 15 & 1 & 1.0 & 2.6 & 2.0 & 170 & & & & \\
\hline 15 & 5 & .93 & 3.0 & 3.3 & 230 & & & & \\
\hline 15 & 10 & .67 & 2.9 & 1.3 & 91 & & & & \\
\hline Site 15 mean & & .88 & 2.8 & 2.2 & 160 & .037 & .029 & 110 & 4 \\
\hline 16 & 1 & 1.0 & 2.8 & 1.5 & 140 & & & & \\
\hline 16 & 5 & 1.1 & 3.1 & & & & & & \\
\hline 16 & 10 & 1.0 & 4.2 & 1.4 & 170 & & & & \\
\hline Site 16 mean & & 1.0 & 3.4 & 1.5 & 160 & .34 & .034 & 150 & 10 \\
\hline 17 & 1 & 1.0 & 4.3 & 1.8 & 400 & & & & \\
\hline 17 & 5 & 1.4 & 3.8 & & & & & & \\
\hline 17 & 10 & .87 & 4.0 & 1.0 & 130 & & & & \\
\hline Site 17 mean & & 1.1 & 4.1 & 1.4 & 190 & .34 & .030 & 180 & 1 \\
\hline 18 & 1 & 1.0 & 3.6 & .79 & 130 & & & & \\
\hline 18 & 5 & 1.1 & 4.2 & & & & & & \\
\hline 18 & 10 & 1.0 & 3.6 & 2.1 & $2.0 * 10^{2}$ & & & & \\
\hline Site 18 mean & & 1.0 & 3.8 & 1.4 & 170 & .48 & .021 & 170 & .8 \\
\hline MEAN & & 1.0 & 3.8 & 1.9 & 190 & .13 & .026 & 160 & 8 \\
\hline S.E. & & .050 & .29 & .20 & 13 & .03 & .003 & 11 & 3.0 \\
\hline
\end{tabular}

${ }^{*}$ Cleared area values do not include the house footprint; they show total cleared area less the house footprint. Total cleared area $=$ cleared area + house footprint. ${ }^{* *}$ No data-value assumed to be the mean of the dataset.

\begin{tabular}{|c|c|c|c|c|}
\hline \multicolumn{5}{|c|}{ FOREST } \\
\hline Site & Bulk density $\mathrm{g} \cdot \mathrm{cm}^{-3}$ & $\mathrm{wt} \%$ C $0-25 \mathrm{~cm}$ & wt\% C $25-75 \mathrm{~cm}$ & Total Soil C Mg.ha ${ }^{-1}$ \\
\hline 1 & .63 & 3.8 & 2.5 & 140 \\
\hline 2 & .48 & 8.8 & 2.8 & 170 \\
\hline 3 & 1.0 & 2.0 & .86 & 98 \\
\hline 4 & .70 & 5.4 & 1.4 & 140 \\
\hline 5 & 1.0 & 3.0 & 2.5 & $2.0 * 10^{2}$ \\
\hline 6 & .46 & 5.3 & 3.5 & 140 \\
\hline 7 & .77 & 4.5 & 7.9 & 390 \\
\hline 8 & .67 & 11 & 3.0 & 290 \\
\hline 9 & .53 & 11 & 5.5 & 290 \\
\hline 10 & .39 & 12 & 2.5 & 160 \\
\hline 11 & .47 & 11 & 12.4 & 420 \\
\hline 12 & 1.0 & 9.6 & 3.7 & 420 \\
\hline 13 & .93 & 5.1 & 2.3 & 230 \\
\hline 14 & 1.1 & 1.5 & .94 & 92 \\
\hline 15 & .86 & 5.6 & 2.6 & 230 \\
\hline 16 & 1.1 & 3.7 & 3.8 & 320 \\
\hline 17 & .91 & 8.5 & 3.2 & 340 \\
\hline 18 & .91 & 5.0 & 2.7 & 240 \\
\hline MEAN & .77 & 6.4 & 3.6 & 240 \\
\hline Standard Error & .24 & .78 & .65 & 25 \\
\hline
\end{tabular}

